\title{
What is Happening to the Distribution of Income in the UK?
}

\author{
A. B. ATKINSON \\ University of Cambridge \\ Fellow of the Academy
}

\section{Introduction}

THE question examined in this lecture has been out of fashion in recent years. In this respect, there is a marked contrast with the situation when the Keynes Lecture Series began 20 years ago. At that time, there was considerable discussion about the distribution of income and about the distributional consequences of government policy. In the 1960s, there had been the rediscovery of poverty in Britain and the launching of the War on Poverty in the United States. New measures for income maintenance were being planned and issues of fairness were much debated with regard to incomes policies.

Along with public interest came scientific research. In the United States, the War on Poverty was accompanied by large-scale research projects, including the negative income tax experiments, and by the founding of the Wisconsin Poverty Research Institute. In Britain, there was a considerable improvement in the availability of official statistics, including the fuller exploitation of existing household surveys such as the Family Expenditure Survey and administrative sources such as the estate duty returns. In the second half of the 1970s, the Royal Commission on the Distribution of Income and Wealth was established.

The position today is different. For the last 10 years there has been little public concern in Britain about the distribution of income, and it does

A revised version of the Keynes Lecture presented at the British Academy, 15 October 1991. C) The British Academy 1993. 
not appear to be high on the political agenda. Yet this is a period which one suspects has seen major changes in the distribution of income. The evidence, as we shall see, is limited in its coverage and in the degree to which it provides an up-to-date picture. But it seems clear that income inequality increased over the 1980s. To see the significance of this development, it is important to place it in historical perspective, and it is with this perspective that $I$ begin.

Before reviewing the evidence about income inequality, I should however make clear that I am not considering in this lecture the reasons why there should be-or why there should not be-concern about inequality, or why income, rather than some other variable, should be the focus of our concern. The mere existence of income differences does not necessarily imply economic injustice, and what one means by injustice depends on underlying moral judgments. These are important matters, but they are not my subject here. In what follows, I am simply assuming that the distribution of income, measured in a conventional manner, is one of the elements which enters social judgments about the state of contemporary Britain.

A second important disclaimer is that I do not discuss in any systematic way the conceptual problems that arise in measuring income inequality. There are major issues concerning the way in which the data are collected and analysed: the definition of the income unit, the treatment of differentsized units, the period over which income is measured, and the definition of income (see Atkinson, 1983, Chapter 3, and Atkinson and Micklewright, 1992, Section 3.4). In what follows, the evidence in general relates to the distribution of annual after tax income among family units, with adjustment for family size, weighted according to the number of individuals. Departures from this 'Base Definition' are noted where applicable.

\section{The Post-War Decades}

In the post-war years, there was a widespread feeling that the distribution of income in Britain was moving in the direction of equality. In 1962, Titmuss summarized prevailing opinion as follows:

Much has been written in recent years about the strongly egalitarian effects of the social and economic policies pursued by British Governments since the end of the Second World War. . . Full employment . . was leading to a steady reduction in wage and salary differentials. . . the wealthy were a disappearing class in Britain. (1962, p. 15).

Kuznets argued in his Presidential Address to the American Economic Association in 1955 that, on the basis of evidence for pre-tax incomes in the United Kingdom (UK), the United States (US) and Germany, 
the relative distribution of income ... has been moving toward equality, with these trends particularly noticeable since the 1920 s but beginning perhaps in the period before the first world war $(1955$, p. 4).

It was in this Address that Kuznets put forward the hypothesis that income inequality tended to increase in the early stages of economic growth but that in more mature economies inequality tended to fall as per capita income increased. This hypothesis of an inverted U-relation between inequality and income came subsequently to be known as the 'Kuznets curve'. According to Kuznets' observations, the US and the UK were comfortably on the second part of the $\cap$ shape.

These conclusions about falling inequality were not accepted by all. The purpose of Titmuss' essay Income Distribution and Social Change was to provide a critique of the evidence on which popular impressions were based. He rightly drew attention to the limitations of the official statistics. To take just one example, the definition of income fell considerably short of a comprehensive measure of command over resources. Awareness of the weaknesses of existing statistical information was one of the reasons that led to the setting up in 1974 of the Royal Commission on the Distribution of Income and Wealth, chaired by Lord Diamond. An important function of the Commission was to improve the available statistics. The distribution of annual after-tax income among tax units shown in Table 1 is based largely on its reports. This is the main official series on the distribution of income, widely known as the 'Blue Book series'.

Before looking at what it shows, I should emphasize that the Blue Book series is still far from perfect. It is still the case, for example, that measured income excludes the imputed rent on owner-occupied houses and major items of fringe benefits. National Insurance contributions are not deducted in arriving at 'after tax' income. Nor, to take another example, do the estimates make any correction for people who only appear in the statistics for part of the year. ${ }^{1}$ For these, and other, reasons, Table 1 can give only a partial picture of the distribution of economic well-being.

Moreover, the Blue Book series departs in certain respects from the Base Definition described above. Table 1 takes no account of family size,

\footnotetext{
${ }^{1}$ Some of the low incomes in the Blue Book estimates relate to tax units which exist for only part of the year:

Part year units comprise women who are widowed or divorced for part of the tax year, new entrants to the work force, people who die during the year and immigrants and emigrants. The effect of including these part year incomes is to increase the measured inequality of the distribution. In 1978/79, their removal from the pre-tax distribution produced a reduction in the Gini coefficient of two percentage points. (Economic Trends, November 1987, p. 98).
} 
Table 1. Blue Book estimates of the distribution of personal after tax income in the UK $1949-1984 / 5$

\begin{tabular}{lccc}
\hline & \multicolumn{2}{c}{ Share of } & Gini \\
\cline { 2 - 4 } & Top $10 \%$ & Bottom $50 \%$ & Coefficient \\
\hline 1949 & 27.1 & 26.5 & 35.5 \\
1954 & 25.3 & 26.3 & 35.8 \\
1959 & 25.2 & 25.0 & 36.0 \\
1962 & 25.6 & 25.8 & 35.6 \\
1963 & 25.4 & 25.8 & 35.6 \\
1964 & 25.9 & 25.2 & 36.6 \\
1965 & 25.4 & 25.8 & 35.4 \\
1966 & 24.5 & 26.8 & 33.7 \\
1967 & 24.3 & 26.8 & 33.5 \\
$1968 / 9$ & 23.6 & 26.6 & 33.2 \\
$1969 / 70$ & 23.6 & 26.4 & 33.5 \\
$1970 / 1$ & 23.9 & 26.1 & 33.9 \\
$1971 / 2$ & 24.1 & 25.9 & 34.2 \\
$1972 / 3$ & 23.6 & 26.8 & 33.1 \\
$1973 / 4$ & 23.6 & 27.0 & 32.8 \\
$1974 / 5$ & 23.2 & 27.0 & 32.4 \\
$1975 / 6$ & 22.3 & 27.4 & 31.5 \\
$1975 / 6$ & 23.1 & 26.7 & 32.6 \\
$1976 / 7$ & 23.2 & 26.9 & 32.6 \\
$1977 / 8$ & 23.3 & 26.5 & 33.0 \\
$1978 / 9$ & 23.4 & 26.2 & 33.5 \\
$1981 / 2$ & 25.6 & 25.2 & 36.0 \\
$1984 / 5$ & 26.5 & 24.9 & 36.0 \\
\hline
\end{tabular}

Sources: 1949 to $1976 / 7$ from Royal Commission on the Distribution of Income and Wealth (1979), Table A.3 p. 167; 1977/8 from National Income and Expenditure, 1980, p. 113; 1978/ 9 to $1984 / 5$ from Economic Trends, 1987, Table A (Gini coefficient for 1978/9 from National Income and Expenditure, 1982, p. 110).

Notes: (a) The data are based on the Survey of Personal Incomes (SPI); only those years are included for which a survey was carried out (from 1949 the survey was quinquennial, with estimates for intervening years being made by extrapolation, the survey becoming annual in 1962).

(b) There is a break in continuity in the series in 1975/6; the earlier figures deduct mortgage interest and other tax-deductible items.

(c) The figures relate to the distribution of tax units; no adjustment is made for differences in unit size.

(d) The figures show the distribution of annual income, net of income tax paid; no adjustment is made for part-year units.

(e) The Gini coefficient is equal to half the expected absolute difference in incomes, relative to the mean, between any two tax units drawn at random from the population: for example, a value of 36 per cent means that, on average, the absolute difference between the incomes of any two tax units is equal to 72 per cent of the mean.

so that an income of $£ 10,000$ is regarded the same whether it has to support one person or a family of four, and each tax unit is counted once whatever its size. While we would not necessarily want to divide the income by four, yielding per capita income, we may want to make an adjustment for family 
size by means of an 'equivalence scale' which varies with family size and composition. Having calculated 'equivalent income' by dividing by this scale, we may then want to count as many incomes as there are people in the tax unit.

Bearing these qualifications in mind, we can see that the Blue Book series in Table 1 shows that in 1949 the top 10 per cent and the bottom 50 per cent of tax units both received about 27 per cent of total after tax income. The fact that the shares were virtually the same means that the top 10 per cent were on average about 5 times better off than the bottom half of the population: in fact 5.1 times. There was however a gradual downward trend until the mid-1970s in the share of the top 10 per cent, there being a total fall of 4.8 percentage points (from 27.1 per cent to 22.3 per cent). At the same time, the share of the bottom 50 per cent rose slightly from 26.5 per cent to 27.4 per cent. This led to a decline in the ratio of their average incomes from 5.1 to 4.1. A different indicator of inequality, the Gini coefficient favoured in official statistics, fell over the quarter century by 4 percentage points. ${ }^{2}$

The fall in income differences between 1949 and 1976 was a noticeable one. ${ }^{3}$ At the same time, as we have just seen, the share of the bottom 50 per cent did not itself rise very much. Most of the redistribution was from the top 10 per cent to the next 40 per cent, or the upper middle income group. It was those already in the upper middle of the income range who gained, not those at the bottom. This may give some indication why a period of recorded income equalization still gave rise to concern about the persistence of relative poverty.

\section{What Do We Know from Official Statistics about the Recent Period?}

So far I have discussed the situation up to the mid-1970s. What has happened since then? The first point to be made in answering this question is that our knowledge in this area remains distinctly limited; indeed the situation with regard to statistics on the overall distribution of income has in certain respects worsened since the 1970s.

A comparison with the situation in Eastern Europe is striking in this

\footnotetext{
2 Around the trend, there was cyclical variation; for discussion of the relationship with the rates of unemployment and inflation-see Nolan (1987).

${ }^{3}$ It would be helpful to attach a confidence interval to the estimated shares, in order to assess the statistical significance of this fall. The estimates are however the product of an elaborate process of adjustment to the initial survey results involving extensive use of extra-sample information-see Ramprakash (1975).
} 
respect. In recent work with Micklewright (Atkinson and Micklewright, 1992), we have been looking at what was known about the distribution of income in Eastern Europe prior to 1990. At the outset, our expectations regarding data availability were not high, influenced by the case of the Soviet Union, of which Bergson had written

Concerning income inequality in the USSR, the Soviet government apparently prefers to withhold rather than to release information (1984, p. 1091).

The situation in Eastern Europe was however quite different. The Central Statistical Offices of a number of Eastern European countries have an impressive record of publications. Evidence about the distribution of earnings in Poland has been collected and published since 1955 (Vielrose, 1978, p. 229), whereas in Britain, the regular collection of statistics on the earnings distribution (the New Earnings Survey) began only in 1970, or 15 years after Poland. In the case of incomes in Poland, information was (in Autumn 1991) available on the household distribution for a range of years up to 1989; data were available for Czechoslovakia on the household distribution of income covering the period 1958-1988; and those for Hungary covered the years $1962-1987$.

In contrast, in Britain in Autumn 1991, the Blue Book income distribution series covered only the period up to 1984/5. The Blue Book series has indeed had a rather chequered history, a history which illustrates how political factors play a role in the availability of statistics in market as well as Communist countries. After being produced for many years, the series was dropped by the government in 1970 . It was reinstated some 5 years later by the Royal Commission. When the Commission was abolished by the newly-elected Thatcher Government in 1979, this improvement was commended and reference made to the work being continued by official statisticians. ${ }^{4}$ However, within two years, the Review of the Government Statistical Services (Cmnd 8236, para 2, page 4) reduced the frequency of production of estimates of the distribution of personal income from every year to every three years. We have therefore only figures for $1978 / 9$, 1981/ 2 and 1984/5, as shown in the lower part of Table 1 . The last of these was published in November 1987, so the figures for 1987/8 are overdue. On telephoning the Central Statistical Office in July 1991, we were however told that there were no definite plans to publish the next set of results.

The official income distribution data in Britain are therefore considerably

4 'The Commission has made a valuable contribution to improving our understanding of the trends in the distribution of income and wealth. As a direct consequence of its recommendations the Governments own statistics are now providing better information in this area and should enable us to carry on the necessary up-dating of the Commission's reports.' (Letter from James Prior, Secretary of State for Employment, 11 June 1979). 
less up-to-date than those of Eastern Europe. Now you may say that there is a difference in the quality of the data. The Eastern European statistics have been criticized for not including, for political reasons, the 'nomenklatura', or the party élite, who derived benefits ranging from the ability to buy in foreign currency shops to privileged housing or medical care. This is true, but it has to be remembered that the UK figures too leave out much of the benefits in kind paid to top earners. So-called fringe benefits are far from minor in importance and include some of the same items, such as privileged medical care. ${ }^{5}$

The lack of recent Blue Book income distribution data is frustrating, since what the figures up to $1984 / 5$ show is very interesting. As may be seen from Table 1, the share of the top 10 per cent in after tax income has begun to rise, after falling for several decades. Between 1975/6 and 1978/ 9 the increase in inequality was slight, but between $1978 / 9$ and $1984 / 5$, a period of 6 years, the share rose by 3.1 percentage points - wiping out two-thirds of the fall between 1949 and the mid-1970s. But it was not a simple reversal of the previous trend: the upper-middle income group did not absorb all of the fall, and the share of the bottom 50 per cent fellsee Table 1-to the lowest level recorded in the post-war period. This intensified the widening in the distribution and the top 10 per cent are now back to having more than 5 times the average of the bottom half.

\section{Evidence from the Family Expenditure Survey}

The Blue Book series on which I have drawn so far

seeks to combine the best features of the available sources (Economic Trends, November 1987, p. 100).

To this end, the Central Statistical Office (CSO) takes the Inland Revenue Survey of Personal Incomes, based on income tax returns, as its starting point but supplements this with information from the Family Expenditure Survey (FES), particularly on those with low incomes. ${ }^{6}$ The way in which it is done means however that one cannot have access to micro-data on individual families. In order to explore more fully what lies behind the

\footnotetext{
${ }^{5}$ In the UK, the Royal Commission on the Distribution of Income and Wealth found that 'there is little doubt that if account were taken of employee benefits, working conditions and other aspects of employment, the dispersion of the earnings distribution would be increased. The effect within the top one per cent of employees must be particularly marked.' $(1979$, p. 233).

${ }^{6}$ For fuller accounts of the construction of the Blue Book estimates, see Stark (1972 and 1978) and Ramprakash (1975).
} 
changes, we have to rely solely on the FES, which has been used extensively in distributional analysis: see for example Jenkins (1991) and Townsend (1991). The FES is an excellent survey, but differential nonresponse and under-reporting of income mean that it provides less satisfactory coverage of the top incomes than does information based on the tax records. ${ }^{7}$ It should also be stressed that, being based on a household survey, the FES data do not cover those people who as you leave this lecture you will see settling down to sleep on the streets of London or those living in institutions. ${ }^{8}$

Results from our own analysis of the FES- work done jointly with Holly Sutherland and Karen Gardiner - are shown in Figure 1, comparing the years 1975 and $1985 .{ }^{9}$ The representation is a little different. In statistical terms, Fig. 1 shows the percentiles of the distribution. These are the numbers 10,20 , etc. marked on the graph, with ' 10 ' indicating the person 10 per cent from the start of the distribution.

In more popular terms, Figure 1 is like the parade of incomes described by Pen (1971). He imagined a parade in which everyone marches past in an hour, with their height corresponding to their income. The height of the marchers begins - after some people walking upside down (businessmen or investors who have made losses) - at about 1' 6 " and then rises very slowly, so that even by the 30 minute point we have only reached some 4 '. By the beginning of the last 3 minutes we have reached $10^{\prime}$ and then it begins to shoot up. Much more so than can be depicted on this diagram, which stops $2 \frac{1}{2}$ minutes before the climax. According to the Guardian Index of Top Executive Pay (Guardian, 13 June 1991), five directors received annual remuneration in excess of $£ 1$ million in 1990 , which made them over 500 feet tall. As Pen said of the people at the very top

their heads disappear into the clouds and probably they themselves do not even know how tall they are. $(1971$, p. 53).

\footnotetext{
${ }^{7}$ On the other hand, estimates based purely on the FES have certain advantages, including avoiding the problem of part-year units.

${ }^{8}$ The composition of the non-household population was examined by the Royal Commission (1978, Appendix L) on the basis of information in the 1971 Census of Population. At that time, 'more than 70 per cent of the total of about 900,000 consisted of people in mental and other hospitals, old people's homes, hotels and boarding houses' $(1978$, p. 238), although this is likely to have changed since then. According to the Blue Book estimates of the distribution of income, in 1972/3 there were 1.2 million tax units living in institutions, out of a total of 28.4 million (Ramprakash, 1975, Table D).

9 The results are derived from the FES Base Tapes. The data relate to family units, and relate to 9,253 family units in 1975 and 9,040 in 1985 . Results given below for 1988 relate to 9,307 family units. The results have been adjusted for differential non-response by applying the grossing-up factors by family type for Great Britain used by the Department of Social Security with a proportionate adjustment for Northern Ireland.
} 


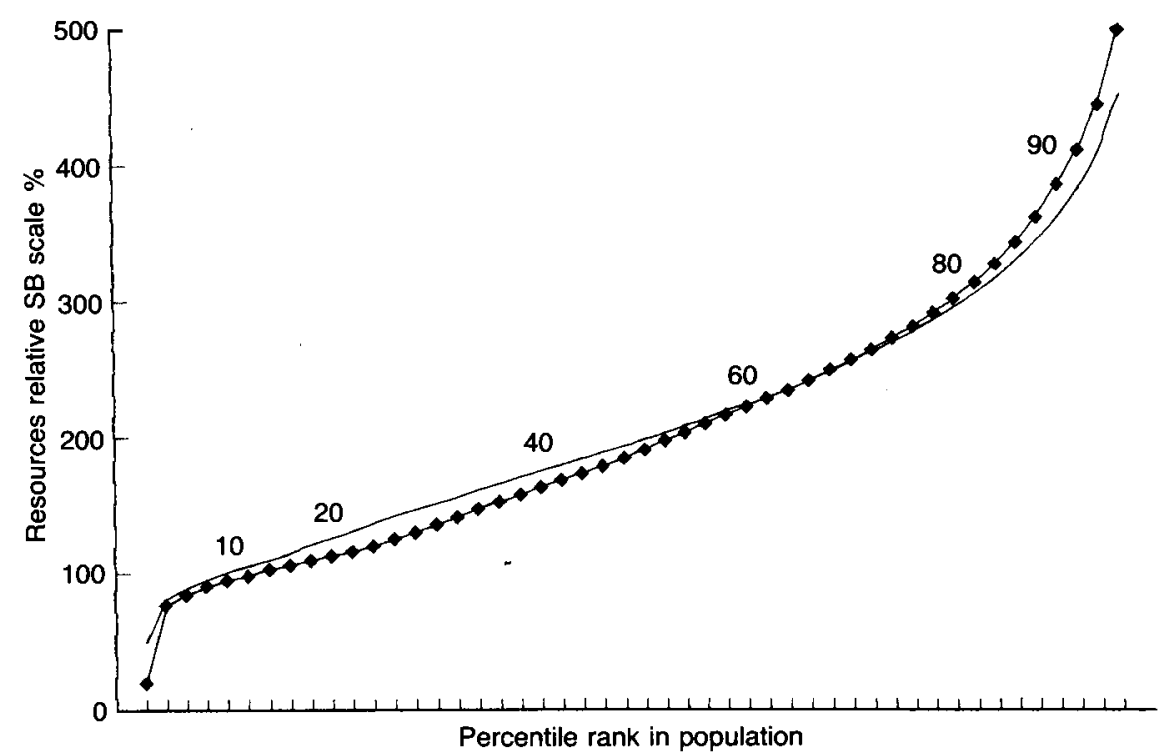

Figure 1. Income parade 1975 (-) and $1985(--)$. Source: FES Base Tapes. The values for 1985 have been adjusted proportionately to give the same mean as for 1975 (222 per cent of the SB scale). The mean for 1985 was 211 per cent of the SB scale in that year. The percentile points are plotted from 2 per cent to 96 per cent.

The richest person at that time he reckoned to be J. P. Getty with a height of at least 10 miles.

The data underlying the parades for 1975 and 1985 shown in Figure 1 follow the Base Definition with two exceptions. First, the FES concept of income is closer to current than to annual. Secondly, the calculations are based not on income but on 'net resources', which is income net of income tax, National Insurance contributions, and outgoings on housing. The deduction of housing costs means that we are considering resources disposable after this relatively fixed item of expenditure has been deducted. ${ }^{10}$ This measure of living standards has been applied for many years in the official study of 'Low Income Families' (Department of Health and Social Security, 1988), but is clearly open to debate-see for example, Johnson and Webb (1990). It does however avoid some of the problems which arise in securing comparable estimates for 1975 and $1985 .^{11}$

10 An earlier study which takes net resources is that by Morris and Preston (1986) with results for 1968, 1977 and 1983. Our estimates differ in that we do not attempt here to construct a measure of annual income.

11 In particular, there is a problem with measures of disposable income before housing costs of securing consistent treatment of housing rebates (for rent and, at that time, rates). If 
Earlier, I noted that the Blue Book series made no allowance for differences in family size. Here net resources are divided by the relevant long-term Supplementary Benefit (SB) scale, SB being at that time the minimum income guarantee programme (now called Income Support). This scale is used primarily to allow for differences in family composition (an equivalence scale), but it also expresses an official view of the movement over time in the minimum safety net standard. The parade shows therefore people's position in relation to the official safety net level, this being measured on the left hand axis. It may be seen that a significant minority of the population are below this level, with, for example, the person 10 per cent from the start of the 1975 parade having net resources around 100 per cent of the SB scale. This reflects the fact that a proportion of those entitled to SB do not in fact claim and that those in work are not covered by the safety net.

The main focus of Figure 1 is on the comparison of the two years, for which purpose the figures have been normalized to have the same mean. The two parades do not of course contain the same people: they are representative of the population at two different dates. Between 1975 and 1985 some people have died and others have been born. Of those present on both occasions, most will be in a different place in the two parades. We cannot follow the individual life histories, to see who has moved up and who has moved down (although this will become possible with the panel study being carried out at the University of Essex). What Figure 1 indicates is the income of the 'corresponding person' who has the same position in the parade. It shows that in the first part of the 1985 parade the corresponding person has a lower income than in 1975 (the 1985 line marked with diamonds lies below), and this continues until we are about two-thirds of the way through the parade. Then we see the 1985 people appearing over the top. At high incomes, such as the ninetieth percentile, they are distinctly taller. Incomes in 1985 were such that those in the lower

income is defined to include such rebates, then we have the practical difficulty that in the FES data such rebates are not always recorded (the net rent being reported or the rebate being paid as a lump sum). It is also the case that between 1975 and 1985 the rents charged to local authority tenants increased substantially while at the same time rebates were increased. An income measure including rebates would give a misleading impression.

If income is defined to exclude housing rebates, then account has to be taken of the fact that prior to April 1983, assistance towards housing costs was provided through Supplementary Benefit. It is necessary to deduct part of the latter payment, which involves additional assumptions (Johnson and Webb, 1990).

The Blue Book series in Table 1 includes rent rebates in the definition of disposable income, but not rate rebates (Ramprakash, 1975, p. 81). No deduction is made of housing costs. 
two-thirds of the distribution had a lower relative income than their counterparts in 1975, whereas those in the top third had a higher relative income. In this sense, the tall have got taller and the short have got shorter.

If, instead of the parade, we were to draw the Lorenz curves, taking the shares in total income of the bottom 5 per cent, 10 per cent, 15 per cent, up to the bottom 95 per cent, then the Lorenz curve for 1985 lies at all these points outside that for 1975 . The share of the bottom 25 per cent, for example, was 11.3 per cent in 1975 but 10.4 per cent in 1985 , and the share of the bottom 50 per cent was 30.3 per cent in 1975 but 27.9 per cent in 1985 . The share of the top 10 per cent was 22.6 per cent in 1975 and had risen to 24.4 per cent by 1985 .

The increase in income inequality from 1975 to 1985 is also demonstrated by summary measures of inequality, a selection of which are shown in Table 2. The Gini coefficient, already used, shows an increase from 28.9 per cent to 32.1 per cent. The other measures of inequality in Table 2 all

Table 2. Summary measures of income inequality in the UK 1975-1988

\begin{tabular}{llll}
\hline & 1975 & 1985 & 1988 \\
\hline Gini coefficient $(\%)$ & 28.9 & 32.1 & 37.5 \\
Generalized entropy index $(\%)$ & & & \\
$\quad c=2\left(\frac{1}{2}\right.$ squared coefficient of & & & \\
variation) & 20.9 & 23.9 & 47.3 \\
$c=0.5$ & 15.1 & 17.8 & 27.2 \\
$c=0$ (logarithmic welfare function) & 16.4 & 19.0 & 28.0 \\
$c=-0.5$ & 20.3 & 22.8 & 34.3 \\
\hline
\end{tabular}

Source: FES Base Tapes, summary indices calculated using the INEQ program written by $F$. A. Cowell from data grouped into 23 ranges.

Notes: (a) The generalized entropy index is defined for $c \neq 0$ or 1 as

$$
I_{c} \equiv 1 /[c(c-1)] 1 / n \Sigma\left\{\left(Y_{i} / y\right)^{c}-1\right\}
$$

where $Y_{i}$ denotes the income of person $i$, $y$ denotes mean income, and $n$ is the number of people. The case where $c=0$ is given by

$$
\mathrm{I}_{0} \equiv-1 / \mathrm{n} \Sigma \operatorname{Ln}\left(\mathrm{Y}_{\mathrm{i}} / \mathrm{y}\right)
$$

where $\mathrm{Ln}$ denotes the natural logarithm.

(b) The distribution refers to net resources, defined as income net of income tax, National Insurance contributions and housing costs. It is expressed as a percentage of the relevant long-term Supplementary Benefit scale.

(c) Earnings are 'normal' earnings and include certain payments in kind. Self-employed income is adjusted by an index to bring it to the mid-point of the relevant year, and is increased by 19.5 per cent to make an approximate allowance for under-reporting. Social security benefits are those in current receipt. Where individual net income is negative, it is set to zero.

(d) The distribution is calculated for family units, with each unit receiving a weight equal to the number of individuals in the unit. 
belong to the 'generalized entropy class' (Cowell and Kuga, 1977, and Shorrocks, 1980). The different values of the parameter $c$ appearing in the index $I_{c}$ attach differing weight to different aspects of inequality. The value of the index when $c=2$ is equal to half the squared coefficient of variation, and this increased by 3 percentage points from a value of 20.9 per cent in 1975 to 23.9 per cent in 1985 . The value $\mathrm{c}=\mathbf{0}$ corresponds to a logarithmic welfare function (Atkinson, 1970), and this increased from 16.4 per cent to 19.0 per cent.

What has happened since the mid-1980s? Table 2 also shows estimates for 1988, indicating that there was a further-indeed sharper--rise in inequality between 1985 and 1988 . The Gini coefficient increased from 32.1 per cent to 37.5 per cent in 1988 . Judged by past changes, this is a large increase. The share of the top 10 per cent increased from 24.4 per cent to 29.2 per cent, a rise of nearly 5 percentage points. The value of the generalized entropy index corresponding to a logarithmic welfare function increased from 19.0 per cent in 1985 to 28.0 per cent in 1988 .

These findings are confirmed by official studies using the FES data. The CSO study of the effect of taxes and benefits on household incomes, referred to as the 'CSO series', compares the distribution of equivalent disposable income in 1977 with that in 1988. These figures differ from those quoted so far, and from the Base Definition, in that the unit of analysis is the household rather than the family unit and that each household counts for 1, regardless of its size. The definition is closer to the Base Definition in that the CSO makes an estimate of annual as opposed to current income. ${ }^{12}$ As is stressed by the authors, the CSO series is not fully consistent over time, but the broad trend is clear. According to the official summary,

the distribution of household income has become more unequal. The bottom quintile group's share of disposable income fell [between 1977 and 1988] from 9.7 per cent to 7.6 per cent whilst the share of the top fifth of households went up from 36 per cent to 42 per cent (Economic Trends, March 1991, p. 107).

The CSO results for the period 1977 to 1988 are shown in Chart 2 in terms of the Gini coefficient (left hand axis) and the ratio of the share of the top 20 per cent to that of the bottom 20 per cent (right hand axis). It may be noted that the rise in the share of the top 20 per cent, and the fall in the share of the bottom groups, was particularly marked after 1985 . The Gini coefficient increased by 6 percentage points between 1985, when it was 29 per cent, and 1988, when it was 35 per cent. This change is in line with

${ }^{12}$ Another significant difference is that disposable income in the CSO series is net of rates (poll tax), but not rent (although rent rebates are included in income). 
that recorded in Table 2, and bears out the finding that there was a more rapid movement towards inequality in the period 1985 to 1988 .

Further confirmation of a sharp rise from 1985 to 1988 is provided by a recent addition to the range of official statistics: the series on 'Households Below Average Income', referred to as 'HBAI'. This again relates to households, rather than families, and is based on current income, but otherwise corresponds to the Base Definition. The series shows the share of the bottom 20 per cent in net income before housing costs falling from 9.8 per cent in 1985 to 8.9 per cent in 1987 , and that of the top 20 per cent rising from 36.2 per cent to 39.1 per cent (Social Trends, 1991, Table 5.16). The figures for net incomes after housing costs, more comparable to those in Table 2, show the share of the bottom 20 per cent falling from 8.6 per cent in 1985 to 7.6 per cent in 1987 , and that of the top 20 per cent rising from 37.6 per cent to 41.0 per cent. Expressed as a ratio, the share of the top 20 per cent relative to that of the bottom 20 per cent rose from 3.7 in 1979 to 4.4 in 1985 and then by considerably more to 5.4 in 1987 .

\section{Conclusions: income inequality in the UK in the 1980s}

To sum up, the traditional-and most extensive-Blue Book set of official estimates of income inequality, those in Table 1, show inequality in the UK as increasing between the mid-1970s and the mid-1980s, a reversal of the previous downward trend. Evidence from the Family Expenditure Survey shows that there can be little doubt that inequality was higher in 1985 than in 1975 . The increase in measured inequality is large by historical standards, and there are grounds to believe that the rise between 1985 and later years in the 1980 s was even more marked.

\section{A World-Wide Trend Towards Inequality?}

Are these findings peculiar to Britain, or is there a world-wide trend towards greater inequality? To answer this question fully requires a detailed study of the sources of evidence in different countries. Here I simply describe briefly in Table 3 some of the findings for a selection of ten OECD countries. ${ }^{13}$

\footnotetext{
13 There has been an extensive literature on the Kuznets' hypothesis using evidence from different countries. Although early studies comparing inequality in different countries found an inverse-U relation, Anand and Kanbur (1984) showed that, when the data were standardized, cross-country comparisons yielded the reverse of the Kuznets pattern. Cross-country data do not in any case allow for country-specific differences. Fields and Jakubson (1990) suggest that the earlier findings had resulted from the fact that Latin American countries tended to have both high inequality and intermediate levels of income. Bourguignon and Morrisson (1990) have alternatively suggested that inequality is associated with a large share of mineral exports.
} 
Table 3. Changes in distribution of income in ten OECD countries

\begin{tabular}{|c|c|c|c|c|}
\hline & \multicolumn{2}{|c|}{$\begin{array}{c}\text { Ratio of share of top } 20 \% \text { to share of } \\
\text { bottom } 20 \%\end{array}$} & \multicolumn{2}{|c|}{ Gini coefficient } \\
\hline & $1970 \mathrm{~s}$ & $1980 \mathrm{~s}$ & $1970 \mathrm{~s}$ & $1980 \mathrm{~s}$ \\
\hline UK & $\begin{array}{l}\text { rose from } 3.7 \text { in } 1977 \\
\text { to } 4.1 \text { in } 1981\end{array}$ & $\begin{array}{l}\text { rose from } 4.1 \text { in } 1981 \\
\text { to } 5.5 \text { in } 1988\end{array}$ & $\begin{array}{l}\text { rose from } 27 \% \text { in } 1977 \\
\text { to } 28 \% \text { in } 1981\end{array}$ & $\begin{array}{l}\text { rose from } 28 \% \text { in } 1981 \\
\text { to } 35 \% \text { in } 1988\end{array}$ \\
\hline US & $\begin{array}{l}\text { rose from } 7.6 \text { in } 1973 \\
\text { to } 8.2 \text { in } 1979\end{array}$ & $\begin{array}{l}\text { rose from } 8.2 \text { in } 1979 \\
\text { to } 10.4 \text { in } 1989\end{array}$ & $\begin{array}{l}\text { rose from } 36 \% \text { in } 1973 \\
\text { to } 37 \% \text { in } 1979\end{array}$ & $\begin{array}{l}\text { rose from } 37 \% \text { in } 1979 \\
\text { to } 40 \% \text { in } 1989\end{array}$ \\
\hline Sweden & $\begin{array}{l}\text { fell from } 5.5 \text { in } 1975 \\
\text { to } 4.6 \text { in } 1980\end{array}$ & $\begin{array}{l}\text { rose from } 4.6 \text { in } 1980 \\
\text { to } 5.4 \text { in } 1988\end{array}$ & & \\
\hline Australia & - & $\begin{array}{l}\text { rose from } 5.0 \text { in } 1981-2 \\
\text { slightly to } 5.2 \text { in } 1985-6\end{array}$ & - & $\begin{array}{l}\text { rose from } 31 \% \text { in } 1981-2 \\
\text { to } 32 \% \text { in } 1985-6\end{array}$ \\
\hline New & & - & & \\
\hline Zealand & - & $\begin{array}{l}\text { rose from } 4.5 \text { in } 1981-2 \\
\text { to } 4.9 \text { in } 1985-6\end{array}$ & - & $\begin{array}{l}\text { rose from } 29 \% \text { in } 1981-2 \\
\text { to } 30 \% \text { in } 1985-6\end{array}$ \\
\hline Canada & $\begin{array}{l}\text { fell from } 10.2 \text { in } 1971 \\
\text { to } 8.1 \text { in } 1979\end{array}$ & $\begin{array}{l}\text { fell from } 10.5 \text { in } 1981 \\
\text { slightly to } 10.3 \text { in } 1988\end{array}$ & $\begin{array}{l}\text { fell from } 39.9 \% \text { in } 1971 \\
\text { to } 36.6 \% \text { in } 1979\end{array}$ & $\begin{array}{l}\text { rose from } 39.5 \% \text { in } 1981 \\
\text { slightly to } 40.4 \% \text { in } 1988\end{array}$ \\
\hline France & - & - & $\begin{array}{l}\text { fell from } 38.4 \% \text { in } 1975 \\
\text { to } 36.4 \% \text { in } 1979\end{array}$ & $\begin{array}{l}\text { rose from } 36.4 \% \text { in } 1979 \\
\text { slightly to } 37.2 \% \text { in } 1984\end{array}$ \\
\hline Italy & $\begin{array}{l}\text { fell from } 9.7 \text { in } 1973 \text { to } \\
5.5 \text { in } 1981\end{array}$ & $\begin{array}{l}5.8 \text { in } 1983 \text { and } \\
5.8 \text { in } 1989\end{array}$ & - & - \\
\hline Finland & $\begin{array}{l}\text { fell from } 4.0 \text { in } 1970 \\
\text { to } 2.9 \text { in } 1981\end{array}$ & $\begin{array}{l}\text { fell from } 2.9 \text { in } 1981 \\
\text { slightly to } 2.8 \text { in } 1985\end{array}$ & $\begin{array}{l}\text { fell from } 27.0 \% \text { in } 1971 \\
\text { to } 20.6 \% \text { in } 1981\end{array}$ & $\begin{array}{l}\text { fell from } 20.6 \% \text { in } 1981 \\
\text { slightly to } 20.0 \% \text { in } 1985\end{array}$ \\
\hline Norway & $\begin{array}{l}\text { rose from } 5.9 \text { in } 1970 \\
\text { to } 6.3 \text { in } 1979\end{array}$ & $\begin{array}{l}\text { fell from } 7.2 \text { in } 1979 \\
\text { to } 6.8 \text { in } 1986\end{array}$ & $\begin{array}{l}\text { rose from } 30.5 \% \text { in } 1970 \\
\text { slightly to } 31.4 \% \text { in } 1979\end{array}$ & $\begin{array}{l}0 \text { fell from } 34.6 \% \text { in } 1979 \\
9 \text { to } 33.0 \% \text { in } 1986\end{array}$ \\
\hline
\end{tabular}

Sources. UK: Economic Trends, March 1991, Tables N and O, data based on Family Expenditure Survey; US: US House of Representatives, Committee on Ways and Means, Overview of Entitlement Programs, 1992, p. 1356, and US Department of Commerce (1991), Table B5, data based on Current Population Survey; Sweden: Björklund (1990), Table A2 (new definition), data based on Survey of Household Income; Australia and New Zealand: Saunders, Stott and Hobbes (1992), Table 5, data based on Australian Income and Housing Survey and New Zealand Household Expenditure and Income Survey; Canada: 1971-1979 from Wolfson (1986), Table 3 (money income per equivalent adult), 1981-1988 from Wolfson (1991, Table 1, total family income), data based on Surveys of Consumer Finance; France: Canceill and Villeneuve (1990), p. 67 and 71, data based on the Enquête sur les Revenus Fiscaux des Ménages; Italy: Brandolini, 1992, Table B7, data based on annual survey of family incomes by the Banca d'Italia; Finland: Uusitalo (1989), p. 34 (disposable equivalent income between persons), data based on Household Budget Survey; Norway: Ringen (1991), p. 6, there is a break in the series in 1979 (which accounts for the two values quoted), data based on samples of tax returns.

Note: 'slightly' is defined as less than 0.3 in the case of the ratio of shares and less than 1 percentage point in the case of the Gini coefficient.

In looking at this table, two qualifications should be borne in mind. First, it should be noted that the data are defined on different bases in each of the countries, so that they are not designed for cross-country comparisons. For example, the UK data are from the Family Expenditure 
Survey, but those for France and Norway are from tax returns. The data for most countries are for disposable income, but those for the US relate to pre-tax income. The aim has been to assemble series that are consistent, not across countries, but across time. It is for this reason that the table focuses on changes in inequality and the comparison between the 1970s and the 1980s. At the same time, the conclusion may be affected by the choice of dates if there is a significant cyclical pattern in equality. In the case of the US, the dates of 1973 and 1979 are taken as broadly 'peak' years in terms of the business cycle, but in other countries they are more a reflection of data availability. This is the second qualification that should be borne in mind when drawing conclusions from Table 3 .

The results are summarized in two ways. First there is the ratio of the share of the top 20 per cent to that of the bottom 20 per cent; secondly, there is the Gini coefficient. One or other is available for each of the countries and in most cases both. The direction of change is indicated by 'rose' or 'fell', although these are qualified by 'slightly' when less than 0.3 in the case of the ratio of shares and less than 1 percentage point in the case of the Gini coefficient.

The pattern in the UK as indicated by the CSO series (that shown in Figure 2) is summarized at the top of Table 3: a rise from the mid-1970s to the early 1980 s, followed by an even sharper rise in the 1980 s. A somewhat similar picture is indicated by the figures for the US, although the timing is different. Over the post-war period as a whole, income inequality in the US has followed a U-shape. According to the Council of Economic Advisers,

from 1947 to 1968 , despite some fluctuations, the dispersion of money income for families fell gradually. Since then, dispersion has risen slowly but steadily . . . Almost one-third of the increase occurred between 1979 and 1982 , when wage and income patterns diverged sharply at the high and low ends of the spectrum (1992, p. 123).

Difference in timing of the bottom of the U-shape is also evident in the case of Sweden, where income inequality appears to have fallen until 1980 or 1981 (Jansson, 1990, Chapter 4), before rising in the 1980s.

Other countries which show rising income inequality in the 1980 s are Australia and New Zealand, but it should be noted that the increase is relatively modest, being around 1 percentage point in the Gini coefficient. In the case of New Zealand, the authors of the study cited note that the Lorenz curves do in fact cross, so that no unambiguous conclusion can be reached about the direction of change.

In fact, in a number of the countries shown in Table 3 there appears to have been only a slight increase, if any, in inequality in the $1980 \mathrm{~s}$. In 


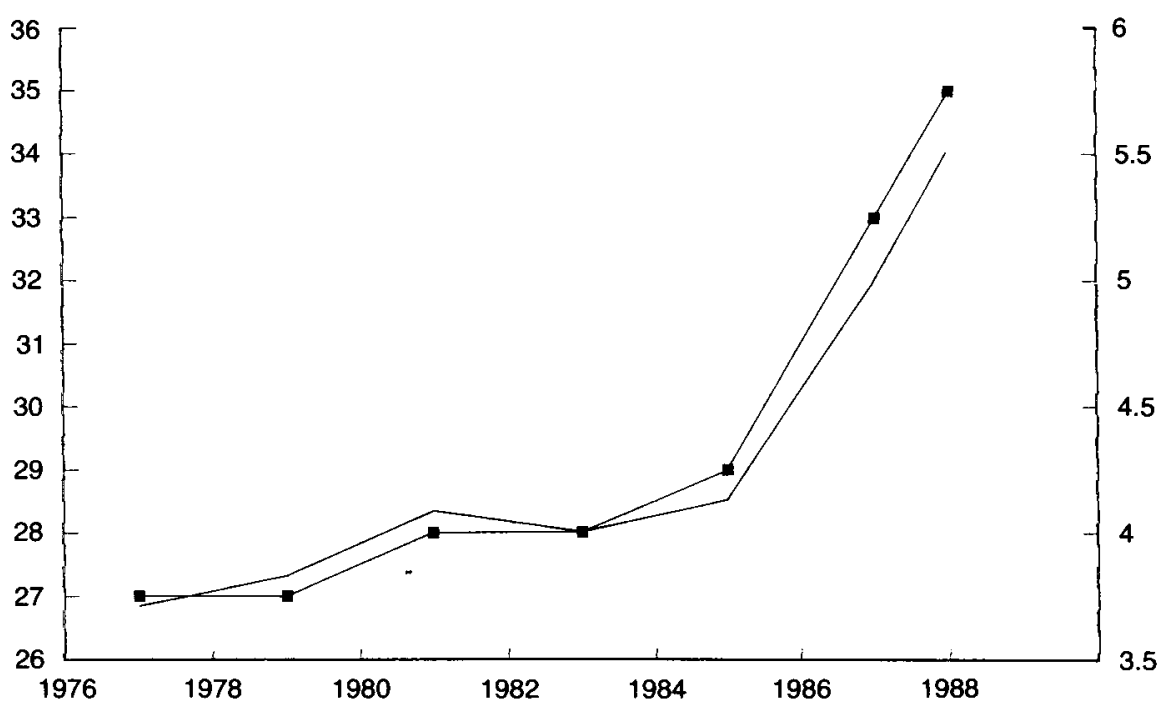

Figure 2. Economic Trends estimates 1977-88. Gini coefficient per cent (left hand axis, - -), ratio share top 20 per cent to bottom 20 per cent (right hand axis, - ). Source: Economic Trends, March 1991, Table N and O, p. 118.

Canada, there is some evidence of a fall over the 1970s, but the changes from 1981 to 1988 were ambiguous: the shares of both the top and the bottom quintiles rose. The overall position up to 1983 has been described as one of 'general stability in income inequality' (Wolfson, 1986, p. 368). Similarly, in the case of France, the situation in the 1980s is described by Canceill and Villeneuve (1990) as one of 'quasi statu quo', with only a slight change from 1979 to 1984 . In Italy, the recorded ratio of the shares of the top 20 per cent and bottom 20 per cent were the same in 1989 and 1983. In Finland, where inequality had been falling in the 1970 s, it continued to fall slightly in the $1980 \mathrm{~s}$. In Norway, where inequality had risen slightly in the 1970s, it fell between 1979 and 1986. As has been noted by Ringen, the trends in the Nordic countries were in different directions:

after 1980, the trends in Finland and Norway are towards equality and in Sweden towards inequality $(1991$, p. 8$)$.

The results cited cover only a selection of countries, but they are sufficient to demonstrate the risks in making any generalization about the world-wide pattern of change in income inequality. A number of countries have experienced a rise in income inequality over the 1980s, but in others there has been no increase, or a fall. This in turn suggests that, while common economic forces have undoubtedly been at work, we have also 
to look at national factors, and particularly national policies, in seeking an explanation of changes in inequality.

\section{Understanding the Changes: the Balance of Conflicting Forces}

I have described the breakdown of the Kuznets hypothesis, at least as far as Britain is concerned, but I suspect that Kuznets himself would scarcely have been taken aback by the finding that the inverse- $U$ shape no longer applies, since he referred frequently to the balancing of conflicting effects. Changes in the distribution of income are the outcome of several forces operating in different directions. As the balance of these forces varies, we may expect the resulting trend in inequality to change direction. In the same way, alternative explanations will have differing importance at different dates.

The balancing of conflicting forces is evident from what is perhaps the most important legacy of Kuznets' approach: the analytical framework for examining the contribution to overall inequality of different sectors of the economy. Suppose that the population can be divided into two groups, A and $\mathrm{B}$, and that $\theta$ denotes the proportion in sector $\mathrm{A}$. Overall inequality depends on $\theta$, on the degree of inequality within each sector, and on the difference between the mean incomes in the two sectors. This is illustrated in Part A of Table 4 for the case where the degree of income inequality is measured by the square of the coefficient of variation, $V^{2}$, this being the member of the generalized entropy family that allows a familiar variance decomposition - see equation (1) in Table 4. Overall inequality is the sum of three terms, involving the inequality within sectors (the first two terms) and the inequality betwen sectors (term in square brackets).

It is this kind of decomposition that underlay Kuznets' original discussion of the impact of the shift from agricultural to non-agricultural sector associated with economic development. Using a numerical example, he examined the implications for overall inequality of a decline in the proportion engaged in agriculture. As the proportion in the two sectors, here represented by $\theta$, varied, he held constant the relative inequality within the sectors (here $\mathrm{V}_{\mathrm{i}}{ }^{2}$ ) and the relative mean incomes in the two sectors. This means that the overall mean income, $y$, must change with $\theta$. For this reason, it is better to replace the terms in $\mathrm{y}_{\mathrm{A}} / \mathrm{y}$ by ones involving $\theta$ and the relative mean incomes in the two sectors, denoted here by $\lambda-$ see the alternative version of equation (1) in Table 4 , denoted by (1'). Parts B and C of Table 4 show the corresponding expressions for the generalized entropy measures. As is clear from these expressions, and as 
Table 4. Decomposition of inequality measures

(A) Squared Coefficient of Variation

$$
\begin{aligned}
V^{2}=\theta & \left(y_{A} / y\right)^{2} V_{A}^{2}+(1-\theta)\left(y_{B} / y\right)^{2} V_{B}^{2} \\
& +\left[\theta\left(y_{A} / y-1\right)^{2}+(1-\theta)\left(y_{B} / y-1\right)^{2}\right]
\end{aligned}
$$

or

$$
1+V^{2}=\left[\theta \lambda^{2}\left(1+V_{A}^{2}\right)+(1-\theta)\left(1+V_{B}^{2}\right)\right] /[\theta \lambda+1-\theta]^{2}
$$

(B) Generalized Entropy ( $c \neq 0$ or 1 )

$$
1 / c(c-1)+I_{c}=\left\{\theta \lambda^{c}\left[1 / c(c-1)+I_{c}{ }^{A}\right]+(1-\theta)\left[1 / c(c-1)+I_{c}{ }^{B}\right]\right\} /[\theta \lambda+1-\theta]^{c}
$$

(C) Generalized Entropy $(c=0)$

$$
\mathbf{I}_{0}=\theta\left\{\mathbf{I}_{0}{ }^{A}-\operatorname{Ln}[\lambda /(\theta \lambda+1-\theta)]\right\}+(1-\theta)\left\{\mathrm{I}_{0}{ }^{\mathbf{B}}-\operatorname{Ln}[1 /(\theta \lambda+1-\theta)]\right\}
$$

where the following definitions apply:

$\theta$ proportion of the population in sector $\mathrm{A}$

y overall mean income

$y_{i}$ mean income in sector $i(i=A, B)$

$V_{i}^{2}$ squared coefficient of variation in sector $i$

$\lambda$ relative mean incomes, $y_{A} / y_{B}$

$I_{c}$ generalized entropy measure with parameter $c$

$I_{c}{ }^{i}$ gencralized entropy measure with parameter $c$ in sector $i$

Notes: (a) $\frac{1}{2} V^{2}=I_{2}$

(b) $\mathrm{y}_{\mathrm{A}} / \mathrm{y}=\lambda /[1-\theta+\theta \lambda] ; \quad \mathrm{y}_{\mathrm{B}} / \mathrm{y}=1 /[1-\theta+\theta \lambda]$.

Kuznets emphasized, the effect of a switch in the importance of the two sectors is not clearcut. Not only does it depend on the degree of inequality within the sectors and on the relative mean incomes, but also it is nonmonotonic in $\theta$. For example, with the same level of inequality in both sectors, overall inequality measured by the squared coefficient of variation rises with $\theta$ until the latter reaches a value of $1 /(1+\lambda)$, and then falls.

This sectoral framework was applied by Kuznets to help understand the effects of industrialization. It may appear attractive to apply the analysis in reverse to the de-industrialization of the British economy. However, it is not clear to me that the explanation of the distribution of personal incomes in Britain today should begin with the generation of factor incomes. There are a number of stages between the determination of factor incomes and the final distribution of income among families. The factor distribution is important for the personal distribution, but there are several intervening mechanisms. Since the days when classical economists could identify payments to factors with payments to individuals, there has been a growth in the role of intermediaries, not least in the role of the state, and its function of taxation and payment of transfer incomes. I am therefore going to reverse the traditional approach, not working from 
factor incomes to personal incomes, but back from the elements which directly affect the personal distribution. ${ }^{14}$

\section{The Shift from Work}

Of the elements which affect personal incomes, one of the most important is whether or not the family is supported by a person in work, which determines whether or not the family has access to the single largest component of factor income - that from wages or self-employment. ${ }^{15}$ In this respect there has been a major shift since the 1970s, as is brought out

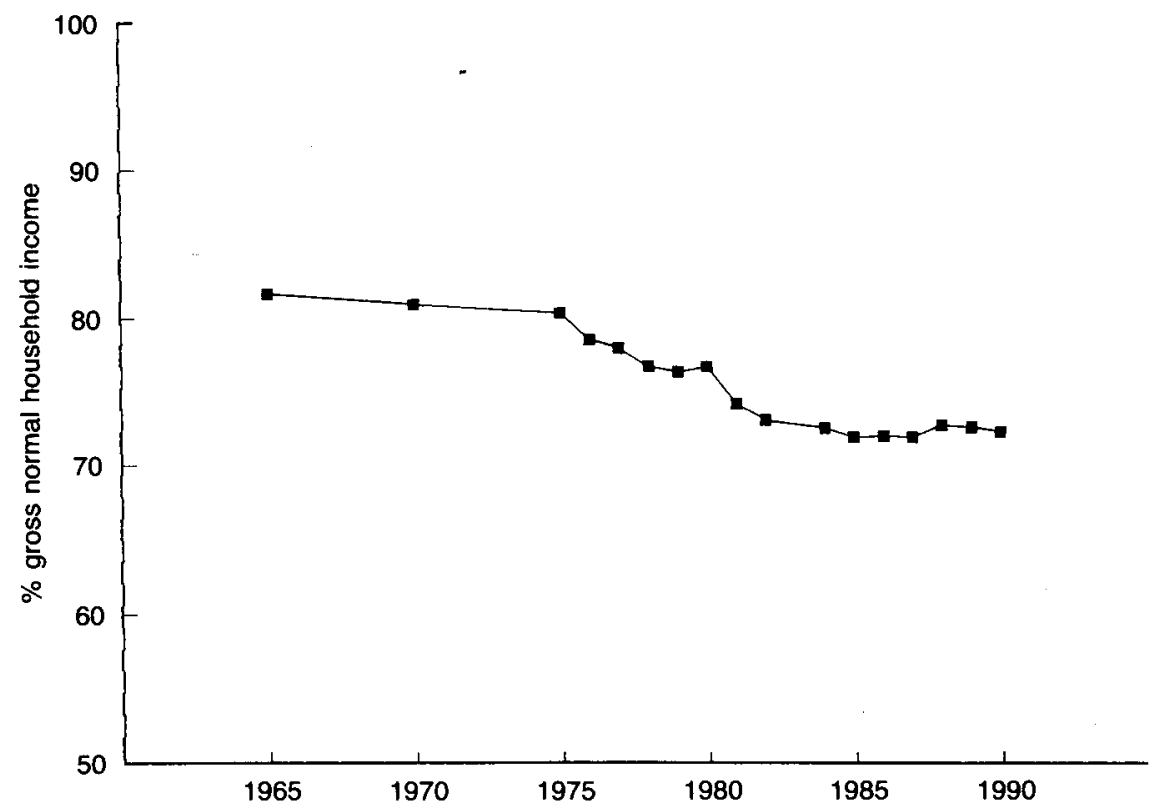

Figure 3. \% Income from work. Sources. 1965-78: Family Expenditure Survey (FES) 1978, Table 40. 1979: FES 1979, Table 46. 1980-82: FES 1983, Table 22. 1984-86: FES 1986, Table 22. 1987-88: FES 1988, Table 22. 1989: FES 1989, Table 22, corrected using FES 1990, Table A. 1990: FES 1990, Table 22. There is a break in the series in 1983 and the figure for that year is not shown.

14 The invitation to give this Lecture emphasized that it did not have to be about Keynes, and I have followed this instruction to the letter, to the extent that I shall not even mention the contribution to the study of distribution for which Keynes is most famous - the supposed constancy of factor shares in national income.

15 The importance of looking at the joint distribution of income and work has been emphasized by Piachaud (1987). 


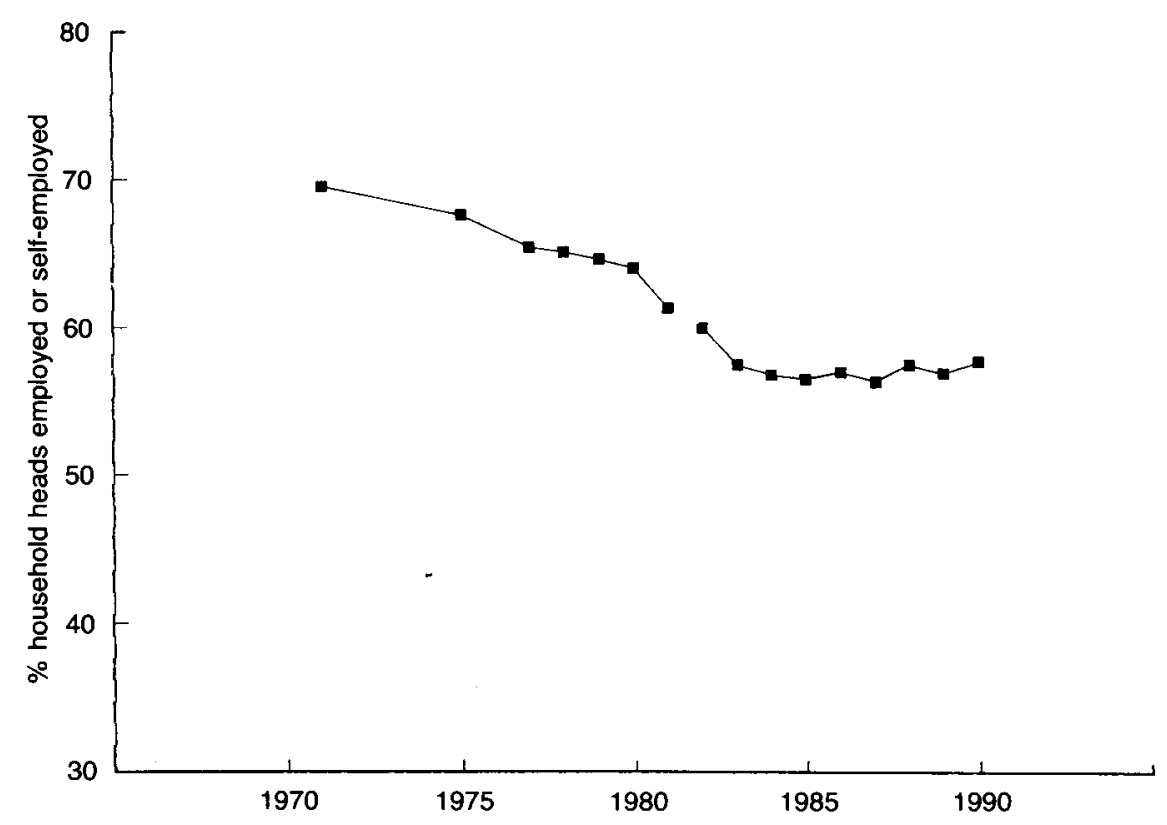

Figure 4. Household head at work. Source: Family Expenditure Survey, Table 1 for all years, except 1975 (Table 40) and 1977 (Table 39). There is a break in the series between 1981 and 1982, when there was a change in the definition of people 'at work'-see FES 1982, Annex A.

by Figure 3, which shows the composition of household gross income in the Family Expenditure Survey (there is a break in the series in 1983 as a result of changes in housing benefit). In the mid-1970s, income from work (earnings plus self-employment income) accounted for more than 80 per cent of the total; by 1982 it had fallen to 73 per cent. There appears to have been a discrete shift between the mid-1970s and the mid-1980s, with the proportion remaining more or less steady since then.

The implications of this shift in the importance of work income depend on how it has been shared. At one extreme, all earned incomes may have been scaled down (or other incomes scaled up) proportionately; at the other extreme, a fraction of the population may have seen their earned incomes reduced to zero. Evidence that the fall in income from work has not been spread proportionately across the population is provided by Figure 4, which shows that the percentage of households where the head was in work (employed or self-employed). This fell by 6.3 percentage points between 1975 and 1981 (when there was a break in the series), and by 3.5 percentage points between 1982 and 1985 . Since then it has levelled out. It did not return to its previous level with the decline in recorded unemployment in the latter part of the 1980s. 
It may be thought that this shift from work between the mid-1970s and the mid-1980s is simply associated with the ageing of the population. However, Britain is ageing less markedly than other countries. Between 1975 and 1985 the proportion of people living in families headed by a person aged over 65 rose by little more than 1 percentage point. ${ }^{16}$ And while it is true that early retirement has expanded in Britain over this period, those aged 55 plus only account for about a third of the increase in the size of the group without a person in work. ${ }^{17}$ If we look at the ages at which the size of the not in work group has increased, then we find increases at all ages: the age group 35-54 contribute less proportionately but broadly the same number absolutely as those aged 65 plus. It is therefore a more general phenomenon than retirement.

This decline in the importance of work cannot but have affected the distribution of income, and I now use the data from the Family Expenditure Survey to explore how far this accounts for the observed increase in inequality between 1975 and $1985 .{ }^{18}$ For this purpose, let us consider two groups of the population: those families where either the husband or wife is in work, denoted by the A, 'Active', sector and those where neither is not in work, denoted by $\mathrm{B} .{ }^{19}$ It may be noted that in treating husbands and wives symmetrically the breakdown differs from that in Fig. 4, which refers to the 'household head'.

To see how such a decomposition may help us learn about the trends, an example may be helpful. In a study of the early retired in the years 1975 and 1985, we found (Atkinson and Sutherland, 1991) that there had been a significant change over this period in the distribution of income for the cohort of men aged 55-64. However, if one considers the two subgroups of those who had retired and those in the labour force, then within

${ }^{16}$ The contribution of demographic change to changes in overall inequality is discussed by, among others, Dinwiddy and Reed (1977) and Mookherjee and Shorrocks (1982). According to Stark (1988) and Jenkins (forthcoming), the experience of the 1980s has in this respect been different, the within-group changes dominating those due to changes in the age composition or in the profile of mean income by age.

17 These calculations refer to the FES sample, and classification of families, described in the next paragraph.

${ }^{18}$ No allowance has been made in these calculations for the value of leisure. One way of treating this is to apply a 'discount' to labour income to allow for the disutility of work; equivalently, we might have a 'target' replacement rate for income out of work. Taking the replacement rate as $3 / 4$, or the discount as a quarter, the increase in inequality between the two years is smaller, but it remains substantial. On the other hand, it does not seem appropriate to value at the same rate leisure which is chosen and leisure which is enforced. ${ }^{19}$ The definition of labour market status poses a number of problems. The distinction here is based on the variable A201 in the FES, which refers to the status 'at present', whereas the income variables refer to past periods. A person who has recently started work may therefore be recorded as in work but not as receiving earnings. 
Table 5. Decomposition of individual distribution of family net resources in the UK 1975 , 1985 and 1988

\begin{tabular}{lccc}
\hline & 1975 & 1985 & 1988 \\
\hline$\theta$ share of sector A (those in work) & 80.6 & 69.1 & 70.3 \\
$\lambda \quad$ relative income in A and B & 1.87 & 1.91 & 2.20 \\
inequality among those in work (A) percentage points & & & \\
$\quad$ Gini & 25.7 & 27.8 & 32.8 \\
$\mathrm{I}_{\mathbf{2}}$ & 17.8 & 19.0 & 40.5 \\
$\mathrm{I}_{0.5}$ & 12.2 & 13.7 & 22.0 \\
$\mathrm{I}_{0}$ & 13.1 & 14.4 & 21.4 \\
$\mathrm{I}_{-0.5}$ & 16.1 & 17.0 & 25.0 \\
inequality among those not in work (B) percentage points & & & \\
Gini & 27.0 & 28.0 & 34.0 \\
$\mathrm{I}_{2}$ & 23.3 & 21.8 & 37.8 \\
$\mathrm{I}_{0.5}$ & 15.1 & 15.3 & 21.7 \\
$\mathrm{I}_{0}$ & 16.1 & 16.2 & 23.1 \\
$\mathrm{I}_{-0.5}$ & 19.9 & 19.3 & 27.6 \\
\hline
\end{tabular}

Source: FES Base Tapes, summary indices calculated using the INEQ programme written by F. A. Cowell from data grouped into 23 ranges.

these groups there had been little change in the distribution. The overall shift reflected the trend to lower rates of labour force participation. For example, the incidence of low incomes could be almost totally accounted for by the change in the relative size of the group in the labour force.

In the case of the whole population, there has been a similar reduction in the proportion 'in work'. In 1975, 80.6 per cent of families contained an adult in work; by 1985 this had fallen to 69.1 per cent-see Table 5 . There was a downward shift of $\mathbf{1 1 . 5}$ percentage points. The effect of this shift depends on the income differential between the two sectors, and we may note that those in work had on average net resources just short of twice that of families without a person in work. This ratio was higher in 1985 than in 1975, but the difference for the two years is not very large.

The effect of the shift from sector A to sector B depends also on the distribution within the two sectors. It is commonly believed that income inequality is greater among the working population than among those not in work, particularly in Britain with its largely flat-rate benefit structure. In fact, this is not true. Typically, for those not in work there is more inequality at the top and the bottom of the income scale. The Lorenz curves for the two groups cross, with that for sector B lying outside at the top and the bottom. As the results for 1975 and 1985 in Table 5 show, all five summary inequality measures used here record higher inequality among those not in work. This difference in sectoral inequality has to be 
taken into account in assessing the impact of the shift between 1975 and 1985: it is in the direction of the more unequal sector.

To quantify the effect of the shift from work, suppose that we take the generalized entropy measure, $\mathrm{I}_{0}$, with $\mathrm{c}=0$, which corresponds to a logarithmic welfare function. The overall rise in inequality from 1975 to 1985 was from 16.4 per cent to 19.0 per cent, a rise of 2.6 percentage points. If, in the formula for $I_{0}$ (in Table 4, Part C) we take the values for 1975 but replace the proportion in the A sector by that for 1985, then the calculated change is a rise of 1.5 percentage points, or more than half the observed change.

In contrast, the effect of the change in relative sectoral incomes is small. If we replace the 1975 value for $\lambda$ by that for 1985 , the difference is 0.2 percentage points; similarly, replacing inequality in the B sector by its 1985 value, the change would be less than 0.1 percentage point. The other main element is the rise in inequality among those in work. If we replace the 1975 value for inequality in the A sector by its 1985 value, then the calculated increase is 1.0 percentage point. Together, the shift in the size of the working population and the rise in inequality among those in work 'account' in an arithmetic sense for almost all of the difference in inequality between 1975 and 1985 .

The quantification of the different effects may depend on the choice of inequality measure. Taking the generalized entropy measure with $c=0.5$, we may calculate that the shift between sectors accounts for a rise in inequality of 1.3 percentage points, and the rise in inequality in $\mathrm{A}$ for 1.2 percentage points, compared to a total increase of 2.7 percentage points. With a value of $c=-0.5$, the figures are 1.8 percentage points and 0.6 percentage points, compared with a total increase of 2.5 percentage points. To give a quite different measure, we may note that in 1975 the proportion of the population living in families with incomes below the SB scale was 9.5 per cent; by 1985 this had risen to 15.1 per cent. While the proportion below this level has risen in both sectors, the shift in weight of the two sectors alone could account for a rise of 3.3 percentage points, or 60 per cent of the change.

On this basis, it appears that the shift from work accounts for around half of the observed rise in inequality. At the same time, it appears from Figures 3 and 4 to have been a structural shift rather than a secular trend. We would not therefore expect the same explanation to apply to the changes post-1985. From Table 5 it may be seen that the size of the A sector did not fall further from 1985 to 1988 , in fact it increased slightly. The inequality within the A sector, on the other hand, continued to increase, and this accounted for some 60 per cent of the observed increase in inequality from 1985 to 1988 . Inequality also increased between 1985 and 
1988 in the B sector, and there was a sizeable rise in the relative income of the A sector, which in three years rose from 1.9 times that in B to 2.2 times. These two elements, which played little or no role in the difference between 1975 and 1985, accounted almost equally for the remainder of the change between 1985 and 1988 .

In what follows I examine in greater depth the determinants of the incomes in the two sectors identified here, considering both their relative level $(\lambda)$ and their distribution within the sector.

\section{Those Not in Work and Transfer Income}

In considering sources of income, one tends to think of the complement of income from work as being income from capital: rent, dividends and interest. This is the classic division by factor shares. However, as far as the household sector is concerned, the second most important source, after income from work, is that of social security benefits. Social security is an example of an intermediate distributional mechanism, as of course are private transfers such as those from occupational pension funds. The social security schemes and the pension funds are institutions that stand between the factor and personal distributions of income.

It is on state transfers that I wish to concentrate here, since through the level of benefits the government has a direct impact on the distribution of income. The weekly net take-home pay of a single person with average earnings rose from $£ 40.70$ in April 1975 to $£ 137.90$ in November 1985, or an increase of 238.8 per cent (Social Security Statistics 1989, Table 46.13, with adjustment for break in series in 1983). Over the same period, the rate of unemployment benefit rose from $£ 9.80$ to $£ 30.45$ a week, or an increase of 210.7 per cent. These figures may sound very similar, but they mean that the ratio of income in work to income out of work rose from 4.15 in 1975 to 4.53 in 1985.

Pensioners have been treated more generously than the unemployed, as is shown by Figure 5, where the single pension is expressed as a percentage of the net take-home pay of a single person with average earnings. In 1974 the Labour government made a distinct improvement in the position of the flat-rate state pension relative to the net earnings, and this was maintained until the early 1980s. Comparing 1975 and 1985, the two years identified on the diagram, the pension was a similar percentage in both years.

From the middle 1980s, however, there has been a marked decline in the relative position of the basic state pension. This reflects the decision by the Conservative government to change the basis for up-rating from 


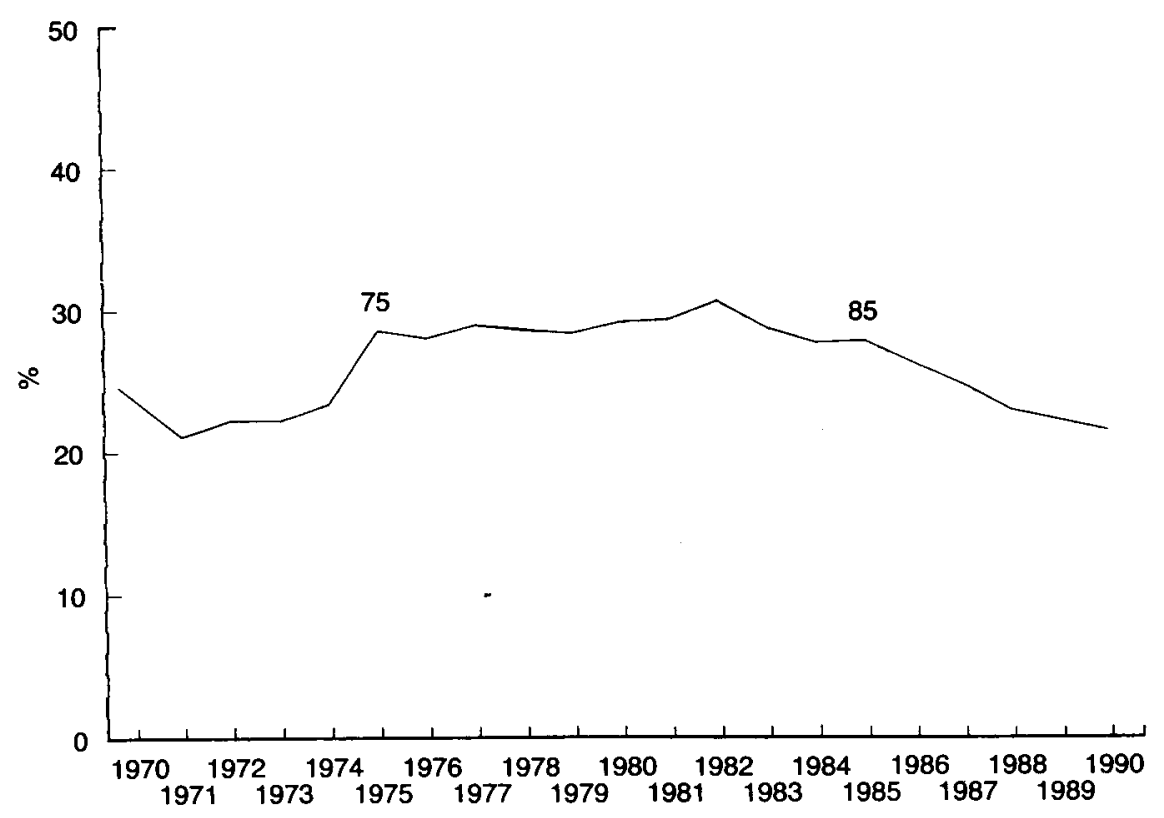

Figure 5. Pension as per cent net earnings. Source: Department of Social Security, Social Security Statistics 1991, Tables H3.06 and H3.10. Earnings are the average of those of all adult full-time workers (male and female) whose earnings are unaffected by absence, after deduction of the income tax and National Insurance (not contracted out) contributions paid by a single person. The earnings series is adjusted for the change in definition in 1983 using the overlapping figure for that year.

earnings to prices, a change which is important in view of the significant growth in real earnings. This is undoubtedly one of the factors responsible for the sharp fall between 1985 and 1988 in the relative income of those not in work (see Table 5). Between November 1985 and April 1988 the basic pension for a single person as a percentage of the net take-home pay of a single person with average earnings fell from 28.5 per cent to 23.5 per cent (Social Security Statistics 1989, Table 46.15).

The level of social security benefits has an important influence on the relative incomes in the two sectors. If, in 1985 , all social security benefits (not including rent or poll tax rebates) had been reduced by 20 per cent, then the relative income of those in work would have risen to 2.22 times that of those not in work, which is almost exactly the increase observed between 1985 and 1988 (see Table 5). (Since this is only an illustrative calculation, no attempt has been made to allow for the income tax payable on benefits or the reduction in housing rebates.) Overall inequality in 1985, measured in terms of half the squared coefficient of variation, would have been increased by some 3 percentage points. This is large by historical 


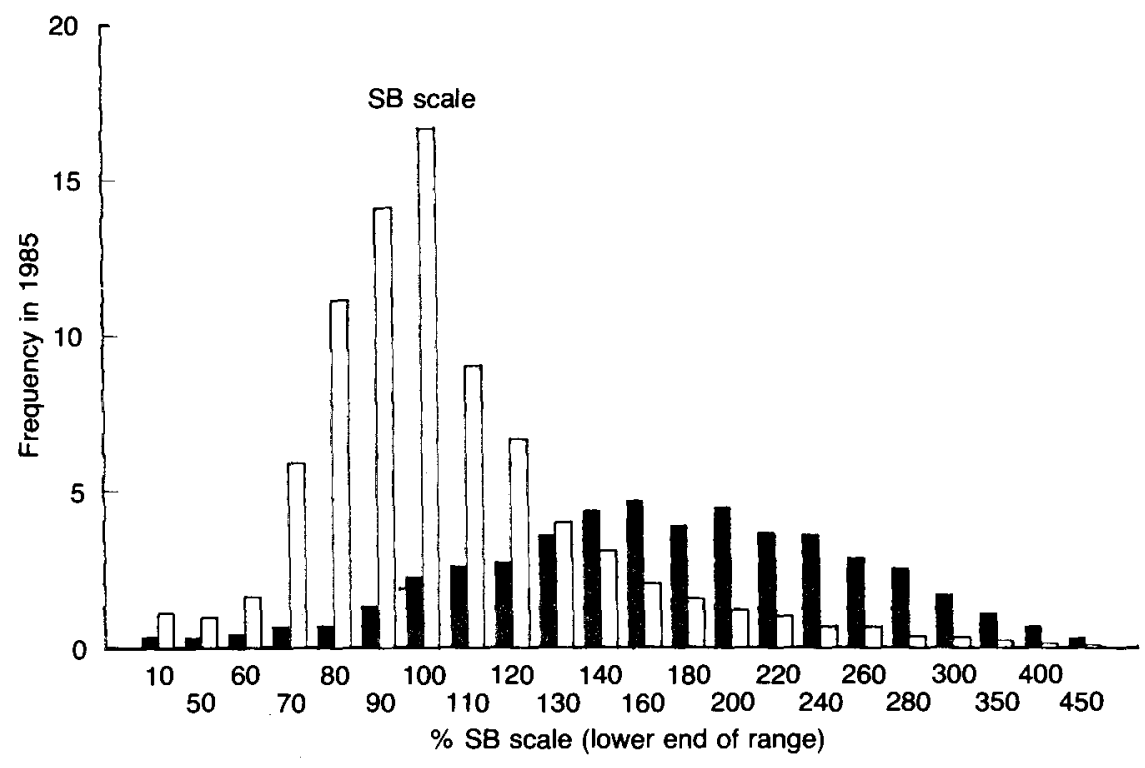

Figure 6. Distribution in relation to SB level. In work ( $\square$ ), not in work ( $\square$ ). Source: FES Base Tape for 1985. Frequencies shown in percentage points per 10 per cent intervals of the SB ratio up to 500 .

standards (although less than the very large increase recorded from 1985 to 1988 in Table 5).

The impact of social security benefits on the overall distribution comes about not just on account of the change in the relative average incomes but also because of the effect on the distribution among those not in work. In Figure 6 are plotted the frequency distributions for the two sectors, the horizontal scale being percentages of the Supplementary Benefit (SB) scale, and the frequencies being expressed as percentages. The frequency distribution for those in work (hatched) has the expected hump-shape, but that for those not in work is more complex. There is a heavy concentration around the SB level, but there are more at the very bottom and a long upper tail. It is this combination that generates a distribution where there is less relative inequality in the middle, but more at the bottom and at the top.

A cut in benefits, while holding the SB scale constant, has the effect of shifting the central mass downwards, away from those with other sources of income, such as occupational pensions, and towards those who are ineligible for or do not claim state transfers. In the case of the retired, it would widen the gap between what Titmuss (1955) described as 'two nations in old age': one group relatively fortunate, benefiting from occupational pensions and private savings, the other group receiving only 
the basic state pension, which left them dependant on means-tested assistance. What is striking is that the position does not seem to have altered greatly since Titmuss wrote. The aim of the state earnings-related pension scheme introduced in 1975 was to provide adequate pensions for those not covered by occupational schemes, but its build up has been slow and it has been seriously scaled-down by the 1986 Social Security Act.

This analysis highlights the importance of social security benefits. This in turn brings us to the question as to what determines benefit levels. As public choice economists have emphasized, the government's actions cannot be treated as purely exogenous. Explaining the distribution of income requires an explanation of government behaviour. Does the change in direction of policy reflect a change in social judgments? Have our concepts of equity changed, becoming less relative and more absolute, so that purely inflation-proofing of benefits is now regarded as an acceptable target? Why has the response in the 1980s to higher unemployment been to make the benefit system less generous to the unemployed? One answer is that there has been a change in the model of unemployment on which the Government bases its decisions, with it now apparently believing in the largely voluntary nature of unemployment. But has there also been a decline in altruism? Has ex ante electoral support for the policy of providing an income guarantee given way to ex post self interest? One can see how this might have happened if people had voted for the welfare state for motives of insurance, but once the recession arrived, the majority found that they were not at risk, and so ceased to give as much weight to the risk of unemployment (Atkinson, 1990).

This is speculation. The main point to be made is that the explanation of trends in the income distribution requires an analysis of public decisions. Intervening institutions such as social security are part of the story as to what has happened to income inequality.

\section{Those in work and Earnings Inequality}

Families with a person in work have on average enjoyed a marked rise in prosperity over the $1980 \mathrm{~s}$, but amongst them was a distinct rise in inequality. In part this rise is due to the behaviour of transfer payments, such as child benefit, received by those in work; in part it reflects the changes made to the structure of income taxation and National Insurance contributions. According to the estimates of Johnson and Webb (1992), the application of the 1979 tax and benefit system to the 1988 distribution of household incomes would have reduced the Gini coefficient by about 3 percentage points. And the reductions in top income tax rates may have 
led at the upper levels to a larger proportion of remuneration appearing in the statistics.

The rise in inequality among those in work also reflects the increased dispersion of pre-tax earnings, which brings us closer to the factor distribution of income. Moving from the level of the family or household to that of the individual, we can find evidence in the New Earnings Survey of widening inequality in individual gross earnings. Figure 7 shows the changes between 1975 and 1990 in the distribution in Great Britain for all full-time workers. The degree of inequality is measured by the ratio of the top decile (earnings of the person 10 per cent from the top) to the bottom decile (earnings of the person 10 per cent from the bottom), referred to as the 'decile ratio'. In 1975, the person at the top decile earned about 3 times the person at the bottom decile; from 1980 the ratio increased, reaching 3.2 in 1985 and 3.36 in 1988. Put another way, the earnings at the top decile rose from 167.5 per cent of the median in 1975 to 186.5 per cent in 1990. The higher earners did particularly well.

To what is this increase in earnings dispersion due? There are a large number of potential explanations which may be derived from the literature on the determination of pay differentials (see Phelps Brown, 1977, for a wide-ranging review). In the Preface to his Theory of Wages in 1932, Hicks referred to

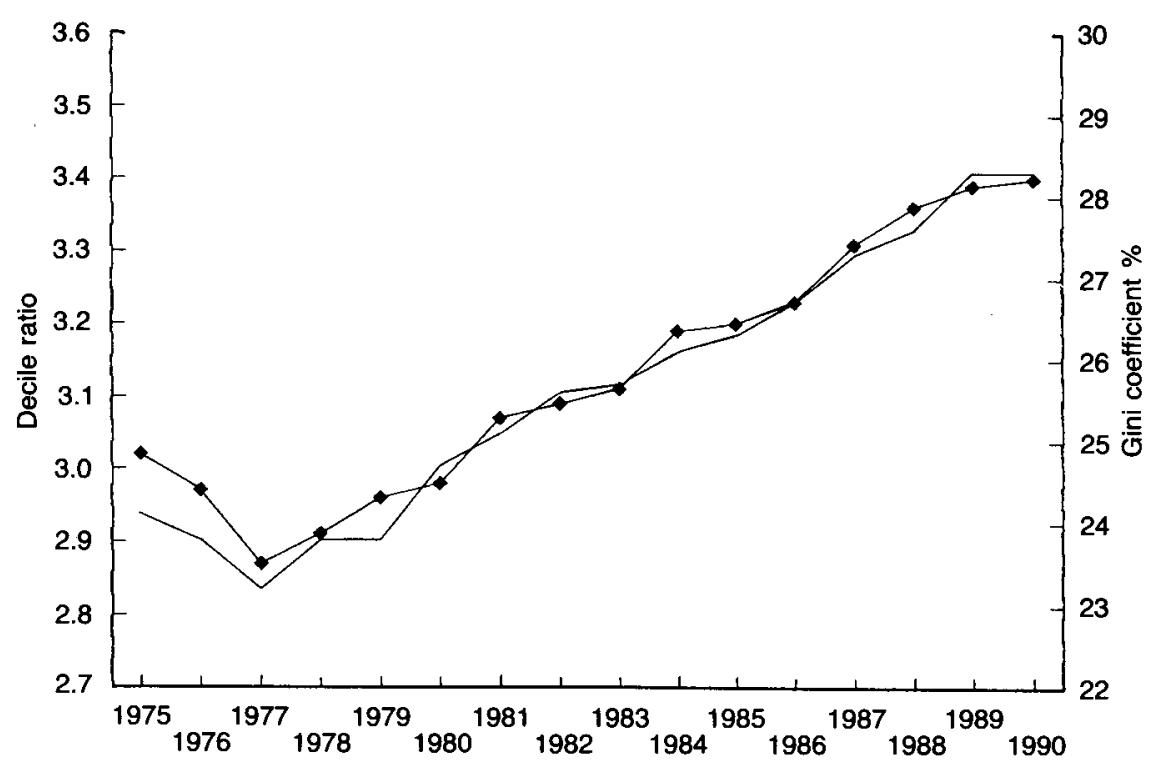

Figure 7. Earnings distribution 1975-90. Gini coefficient (right hand axis, $\longrightarrow$ ), decile ratio (left hand axis, - $\longrightarrow$. Source: Atkinson and Micklewright (1992), Table BE1. 
The historical fact which dominates the wage-history of the present century $\ldots$ is the growth of Trade Union power and the development of State Regulation of Wages (Hicks, 1932, p. x).

One possible explanation is that there has been a reversal of these historical facts. It certainly seems possible that pressures for equalization have been reduced by the abandonment of incomes policies (see Adams, 1988), and the dismantling of much of the Wages Council provisions to protect low paid workers. A role may also have been played by the changes in social security provisions which have had the effect of making people accept jobs paying less than in their previous employment. How far union bargaining power has been reduced at shop floor levels is more open to question, as is the impact of reduced union power on earnings dispersion.

Alternatively, is increased dispersion attributable to Kuznets-like intersectoral shifts - the de-industrialization hypothesis? Employment has moved away from manufacturing towards services, but are services characterized by greater inequality? In Table 6 are shown the changes in earnings dispersion by industry between 1986 and 1990, measured by the decile ratio. The figures relate to workers paid on adult rates (and hence are different from those in Figure 7, which cover all workers). It appears that the service industries are not unambiguously characterized by greater earnings dispersion. If we take the distributive trades, hotels and catering, then the ratio in 1986 was exactly equal to that for the work force as a whole, bearing out the truth of Napoleon's statement that we are a nation of shopkeepers. For banking and financial services the decile ratio is greater (a ratio of 3.75), but for construction, transport and communication, and 'other services' it is less. Moreover, within each of the industrial groups, the decile ratio increased between 1986 and 1990. For example, the decile ratio increased from 3.11 to 3.41 in distribution; in banking it went from 3.75 to 4.19 . All the industrial groups examined, including manufacturing, show a significant rise in inequality, apart from 'other services'. It appears that we have to explain what has happened within industrial sectors as well as between these sectors. ${ }^{20}$

Moreover, the explanation cannot be peculiar to the policies of the British government, since the trend is found in other countries. Green, Coder and Ryscavage (1992) made use of data on five OECD countries (Australia, Canada, Sweden, US and West Germany) from the Luxembourg

20 The same kind of finding has been reached in other countries. In the US for example, Grubb and Wilson (1989) concluded that inter-sectoral shifts appeared to be of some importance, but that

the trends seem to be driven chiefly by developments within labour force groups, rather than movements among them $(1989$, p. 3). 
Table 6. Earnings inequality by industry: all full-time employees paid on adult rates (earnings not affected by absence) Great Britain

\begin{tabular}{llc}
\hline & \multicolumn{2}{c}{ Ratio of top to bottom decile } \\
\cline { 2 - 3 } & 1986 & 1990 \\
\hline All industries and services & 3.11 & 3.30 \\
All manufacturing & 2.93 & 3.10 \\
All non-manufacturing & 3.19 & $\mathrm{n} / \mathrm{a}$ \\
Agriculture, forestry and fishing & 2.17 & 2.50 \\
Energy and water supply & 2.49 & 2.83 \\
Construction & 2.57 & 2.96 \\
Distribution, hotels and catering & 3.11 & 3.41 \\
Transport and communication & 2.53 & 2.64 \\
Banking and financial services & 3.75 & 4.19 \\
Other services & 2.97 & 3.01 \\
\hline
\end{tabular}

Source: 1986: New Earnings Survey (NES) 1986, Part B, Table X2. 1990: NES 1990, Part A, Table X2.

Note: The lower part of the table shows the results for all single digit SIC codes outside manufacturing.

Income Study, covering two dates: broadly the beginning of the 1980s and the mid-1980s. The data, which cover the wages and salary income received by male heads of households aged 25 to 54 years working full time and year round, suggest that the

earnings of the highest paid men in each of the countries examined were becoming more concentrated in the 1980s (Green et al., 1992, p. 11).

In all five countries, the share of the top 20 per cent in total earnings increased. Outside North America, there was little change at the bottom, and it was Canada and the US that showed the largest overall increase in dispersion, the Gini coefficient rising by 3 and 4 percentage points, respectively. Gottschalk and Joyce (1991), adding France, Netherlands and the UK to the sample, show that, despite the large differences in the movements in average real wages in the eight countries, in all cases the upper percentiles performed better. The decile ratio widened by amounts varying from 1 per cent per year (Australia and Netherlands) to 4 per cent per year or more in North America. In contrast to the situation for the distribution of total income, where we found a diversity of experience, the earnings distribution appears to have moved towards greater inequality, particularly at the top, in a range of countries. 


\section{Conclusions}

There are many aspects of the distribution of income which I have not discussed in this lecture. I have said nothing about the distribution of capital. What about the attempts by Mrs Thatcher to create a propertyowning democracy through privatization $?^{21}$ I have not discussed the gender distribution of income and such difficult, and important, issues as the distribution of income within the household. I have not discussed income mobility-either within a lifetime or across generations.

Much therefore remains undiscussed. At the same time, I have tried to do two things. The first is to document the changes which are taking place. Whether or not income inequality is increasing is a contentious subject, and statistical evidence can be abused and misused. As I have stressed, the resources devoted to this area have diminished; we have no body comparable to the Royal Commission. In the first part of the lecture, I have looked at the evidence from different directions, setting it in both historical and international context. It is clear to me that the 1980s have seen a departure from the historical trend, with a definite rise in inequality. There are grounds for believing that the rise between 1985 and later years in the 1980 s was even more marked. Rising inequality in the 1980 s is found in some countries, such as the US, but it is not a universal phenomenon, and in some countries inequality changed little or fell.

The second aim has been to identify some of the elements which should enter an explanation of the trend to increased inequality. I have highlighted two aspects - the shift from work and the rise in earnings inequality - which in my judgment need to receive particular attention when considering the rise in inequality between the mid-1970s and the mid1980s. The subsequent rise after 1985 can again be attributed to increased earnings dispersion, but the period also saw a widening income difference between those in work and those not in work, and a rise in inequality within the latter group. In seeking to explain these different parts of the story, economic factors undoubtedly play an important role. The observation that the earnings dispersion has increased in a range of countries

21 The effect of this should not be exaggerated. The proportion of share-holders has indeed risen, but this still leaves the majority of the population without holdings. The most important privatization has been that of council houses, but the Inland Revenue estimate that the maximum effect is likely to have been a 1 percentage point reduction in the Gini coefficient by 1988 (Economic Trends, October 1990, pp. 145-6). In fact the distribution of wealth, according to the Inland Revenue estimates, showed little change over the 1980s. This represents a departure from the long-run pattern, which had seen a fairly steady fall in the degree of concentration since the 1920s (Atkinson and Harrison, 1978). 
suggests that there may be common economic determinants. But these are less relevant to the substantial proportion of the population (now 3 in 10 families) without income from work. We need also to give weight to considerations which do not typically appear in the textbook account of the distribution of income. I have stressed the role of intervening institutions, such as the social security system and the political process that determines transfer payments. Differences in national policies are one reason why there is less similarity of experience across countries when it comes to the distribution of income.

Like most lectures which have a question mark in their title, I have not provided an answer. I would however like to leave you with one concluding reflection. It has been suggested to me in the past that the distribution of income did not change much and that it was therefore either unimportant or uninteresting. Changes in the distribution were of second-order importance. Now, such stability may have resulted from a general tendency to immobility or it may have reflected the fact that, at certain periods, there was a broad balance between a variety of forces operating in different directions. It is my impression from the evidence of the 1980s that the latter is the case. There are certainly a variety of mechanisms at work and there is no reason to expect that they will always balance each other, nor that the same explanations will apply at all dates. The future is likely to be, in this respect, an interesting one.

Note. The lecture is based on work carried out as part of the Welfare State Programme at STICERD, LSE, supported by the ESRC (Programme Grant X206 32 2001). I am particularly grateful to Karen Gardiner and Holly Sutherland for allowing me to draw on our joint research. Most helpful comments on earlier versions have been made by Peter Hart, John Hills, Stephen Jenkins, Alan Milward, Henry Phelps Brown, Nick Stern and Holly Sutherland, but they are not to be held responsible in any way for the views expressed.

\section{References}

Adams, M., 1988, 'The distribution of earnings 1973 to 1986', Department of Employment Research Paper 64, London.

Anand, S. and Kanbur, R., 1984, 'Inequality and development: a reconsideration', in H. P. Nissen, ed., Towards Income Distribution Policies: From Income Distribution Research to Income Distribution Policy in LDCs, EADI, Padenburg.

Atkinson, A. B., 1970, 'On the measurement of inequality', Journal of Economic Theory, vol. 2, 244-263.

Atkinson, A. B., 1983, The Economics of Inequality, second edition, Clarendon Press, Oxford. 
Atkinson, A. B., 1990, 'Income Maintenance for the Unemployed in Britain and the Response to High Unemployment', Ethics, vol. 100, 569-585.

Atkinson, A. B. and Harrison, A. J., 1978, Distribution of Personal Wealth in Britain, Cambridge University Press, Cambridge.

Atkinson, A. B. and Micklewright, J., 1992, Economic Transformation in Eastern Europe and the Distribution of Income, Cambridge University Press, Cambridge.

Atkinson, A. B. and Sutherland, H., 1991, 'Two nations in early retirement?: the case of Britain', Welfare State Programme Discussion Paper 56, STICERD, $L S E$.

Bergson, A., 1984, 'Income inequality under Soviet socialism', Journal of Economic Literature, vol. 22, 1052-1099.

Björklund, A., 1990, Unemployment and income distribution: time-series evidence from Sweden', Swedish Institute for Social Research Discussion paper 3/1990, Stockholm.

Bourguignon, F. and Morrisson, C., 1990, 'Income distribution, development and foreign trade: a cross-sectional analysis', European Economic Review, vol. 34, $1113-1132$.

Brandolini, A., 1992, 'A Description and an Assessment of the Sample Surveys on the Personal Distribution of Incomes in Italy:', Discussion paper, Servizio Studi, Bank of Italy.

Canceill, G. and Villeneuve, A., 1990, 'Les inégalités de revenus: quasi statu quo entre 1979 et 1984 pour les salariés et les inactifs, Economie et Statistique, No. $230,65-74$

Council of Economic Advisers, 1992, Economic Report of the President, US Government Printing Office, Washington, DC.

Cowell, F. A. and Kuga, K., 1977, 'Additivity and the Entropy Concept: An Axiomatic Approach to Inequality Measurement', Institute of Social and Economic Research, Osaka University, Discussion Paper 96.

Department, of Health and Social Security, 1988, Low Income Families, London.

Dinwiddy, R. and Reed, D., 1977, The Effects of Certain Social and Demographic Changes on Income Distribution, Royal Commission on the Distribution of Income and Wealth, Background paper No. 3, HMSO, London.

Fields, G. S. and Jakubson, G. H., 1990, 'The inequality-development relationship in developing countries', Discussion paper, Cornell University.

Gottschalk, P. and Joyce, M., 1991, 'Changes in earnings inequality-an international perspective', LIS Working Paper 66, Luxembourg.

Green, G., Coder, J. and Ryscavage, P., 1992, 'International comparisons of earnings inequality for men in the 1980s', Review of Income and Wealth, vol. $38,1-16$.

Grubb, W. N. and Wilson, R. H., 1989, 'Sources of increasing inequality in wages and salaries, 1960-80', Monthly Labor Review, April, 3-13.

Hicks, J. R., 1932, The Theory of Wages, Macmillan, London.

Jansson, K., 1990, Inkomst- och förmögenhetsfördelningen 1967-1987, Bilaga 19, Finansdepartementet, Stockholm.

Jenkins, S. P., 1991, 'Income inequality and living standards: changes in the 1970s and 1980s', Fiscal Studies, vol. 12, 1-28. 
Jenkins, S. P., forthcoming, 'Recent trends in UK income inequality', in D. Slottje, ed., Research on Economic Inequality, vol. 4, JAI Press, Greenwich, Connecticut.

Johnson, P. and Webb, S., 1990, Poverty in Official Statistics: Two Reports, IFS Commentary 24, London.

Johnson, P. and Webb, S., 1992, 'Recent Trends in UK Income Inequality: Causes and Policy Responses', Royal Economic Society conference.

Kuznets, S., 1955, 'Economic growth and income inequality', American Economic Review, vol. 45, 1-28.

Mookherjee, D. and Shorrocks, A., 'A decomposition analysis of the trend in UK income inequality', Economic Journal, vol. 92, 886-902.

Morris, N. and Preston, I., 1986, 'Inequality, poverty and the redistribution of income', Bulletin of Economic Research, vol. 38, 277-344.

Nolan, B., 1987, Income Distribution and the Macroeconomy, Cambridge University Press, Cambridge.

Pen, J., 1971, Income Distribution, Allen Lane, London.

Phelps Brown, E. H., 1977, The Inequality of Pay, Oxford University Press, Oxford.

Piachaud, D., 1987, 'The distribution of income and work', Oxford Review of Economic Policy, vol. 3, 41-61.

Ramprakash, D., 1975, 'Distribution of income statistics for the United Kingdom, 1972/73: sources and methods', Economic Trends, No. 262, 78-96.

Ringen, S., 1991, 'Households, standard of living, and inequality', Review of Income and Wealth, vol. 37, 1-13.

Royal Commission on the Distribution of Income and Wealth, 1978, Report No. 6 Lower Incomes, Cmnd 7175, HMSO, London.

Royal Commission on the Distribution of Income and Wealth, 1979, Report No. 7 Fourth Report on the Standing Reference, Cmnd 7595, HMSO, London.

Saunders, P., Stott, H. and Hobbes, G., 1991, 'Income inequality in Australia and New Zealand: international comparisons and recent trends', Review of Income and Wealth, vol. 37, 63-79.

Shorrocks, A. F., 1980, 'The class of additively decomposable inequality measures', Econometrica, vol. 48, 613-625.

Stark, T., 1972, The Distribution of Personal Income in the United Kingdom 19491963, Cambridge University Press, Cambridge.

Stark, T., 1978, 'Personal incomes', in W. F. Maunder, ed., Reviews of United Kingdom Statistical Sources, vol. VI, Pergamon Press, Oxford.

Stark, T., 1988, 'The changing distribution of income under Mrs Thatcher' in F. Green, ed., The Restructuring of the UK Economy, Harvester, London, 177-196.

Titmuss, R. M., 1955, 'Pension systems and population change', Political Quarterly, $26,152-166$.

Titmuss, R. M., 1962, Income Distribution and Social Change, Allen and Unwin, London.

Townsend, P., 1991, The Poor Are Poorer: A Statistical Report on Changes in the Living Standards of Rich and Poor in the United Kingdom 1979-1989, Statistical Monitoring Unit, Department of Social Policy and Social Planning, University of Bristol. 
US Department of Commerce, 1991, Money Income of Households, Families, and Persons in the United States: 1990, Current Population Reports, Series P-60, No. 174, Washington DC.

Uusitalo, H., 1989, Income Distribution in Finland, Central Statistical Office of Finland, Helsinki.

Vielrose, E., 1978, 'Patterns of the distribution of earnings in Poland' in W. Krelle and A. F. Shorrocks, eds., Personal Income Distribution, North-Holland, Amsterdam.

Wolfson, M., 1986, 'Stasis amid change - income inequality in Canada 1965-1983', Review of Income and Wealth, vol. 32, 337-369.

Wolfson, M., 1991, 'Inequality and Polarisation: Is There a Disappearing Middle Class in Canada?', Analytical Studies Branch, Statistics Canada. 